\title{
Plasma $\mathrm{Na}^{+}, \mathrm{K}^{+}$-AT Pase Activity In Some Cardiovascular Diseases in Elderly
}

\author{
A. L. Al-Malki and Taha A. Kumosani \\ Department of Biochemistry, Faculty of Science, \\ King Abdulaziz University, Saudi Arabia
}

\begin{abstract}
Cardiovascular diseases, (CVD), are the major cause of early mortality, accounting for almost 25\% of deaths globally. CVD events are the net result of integration of several risk factors namely; aging, obesity, hypercholesterolemia, hypertension, diabetes mellitus, smoking and life style.

Saudi Arabia has gone through significant urbanization over the last 40 years with significant improvement in social and economical status. This has led to change in lifestyle, accommodating more of the Western habits with respect to diet and physical activity. These factors have either led or augmented other risk factors of CVD.

The aim of this study is to provide a helpful test that could be used for the early diagnosis and prognosis of CVD by advancing age through studying plasma activity of the enzyme $\mathrm{Na}^{+}, \mathrm{K}^{+}$-ATPase in different classes of CVD such as valvular heart disease, ischemic heart disease, arrhythmia and heart failure in relation to other biochemical parameters as plasma glucose, urea, creatinine, triglyceride, cholesterol, $\mathrm{HDL}, \mathrm{LDL}, \mathrm{Na}, \mathrm{K}, \mathrm{Mg}, \mathrm{Ca}, \mathrm{Cl}$ and $\mathrm{P}$ besides the relevant plasma enzymes as $\mathrm{CK}$, $L D H, A S T, A L T$ compared to a matched normal control group.

A total of 95 blood samples were collected from patients of different CVD, in addition to 20 blood samples from normal controls. The age for both groups ranged between 50 and 85 years of both sexes, (78 females and 37 males).

The results point to a statistically significant increase in $\mathrm{Na}+\mathrm{K}+$-ATPase activity in most of CVD patients groups under study. Other biochemical parameters showed almost the well known clinically agreed upon pattern. It could be concluded that $\mathrm{Na}^{+}, \mathrm{K+}+$-ATPase should be added as a predictor test for the diagnostic and prognosis of cardiovascular diseases.
\end{abstract}

\section{INTRODUCTION}

Aging is defined as the regression of physiological function with advancement of age. In the heart there is increased fat, collagen and elastic tissue. In people over 75 years old, heart failure occurs ten times more often than in younger adults. CVD, affect $50 \%$ of those over the age of 65 and is a leading cause of death. Mortality from heart disease has declined significantly in the United States over the last three decades, probably due to improved medical treatment and the active information campaigns to educate people about smoking hypertension and hypercholesterolemia which have 
been recognized as the three major risk factors of CVD.

It has been found that activity of erythrocyte sodium pump declines with aging in rabbits, as a result of a reduction in the number of $\mathrm{Na}^{+}, \mathrm{K}^{+}$ATPase units ${ }^{(\mathbf{1})}$. A positive correlation between urinary $\mathrm{Na}^{+} / \mathrm{K}^{+}$ ratio and $\mathrm{Na}^{+}, \mathrm{K}^{+}$-ATPase activity of erythrocyte membrane was found in human female adolescents either with normal blood pressure or with a family history of hypertension, suggesting significant correlations in terms of the abnormal membrane cation fluxes associated with essential hypertension $^{(2)}$

The activity of cardiac $\mathrm{Na}^{+}, \mathrm{K}^{+}$ATPase from young guinea pigs is significantly higher than those from the older. Activity of $\mathrm{Na}^{+}, \mathrm{K}^{+}$-ATPase in young tissue preparations was less inhibited by ouabain than in older tissue preparations. These differences may be related to the observations that young animals and humans are less sensitive to cardiac glycosides than adults $^{(3)}$.

The age-dependent change in myocardial $\quad \mathrm{Na}^{+}, \quad \mathrm{K}^{+}$-ATPase concentration could be ascribed to variation in the ratio between the amount of $\mathrm{Na}^{+}, \mathrm{K}^{+}$-ATPase and muscle mass during development. Since myocardial $\mathrm{Na}^{+}, \mathrm{K}^{+}$-ATPase is the receptor for cardiac glycosides, this may in part explain the situation in the young age ${ }^{(4)}$.

$\mathrm{Na}^{+}, \mathrm{K}^{+}$-ATPase is essential for excitability and contractility of muscle tissue. The decrease in concentration of the pump in skeletal muscle may contribute to the limitation of exercise capacity in congestive heart failure ${ }^{(5)}$. At the same time it was found that
$\mathrm{Na}^{+}, \quad \mathrm{K}^{+}$-ATPase activity was significantly reduced in the untreated hypertensive patients when compared with normal controls ${ }^{(6)}(8)$.

\section{AIM OF WORK}

In Saudi Arabian population aged 30-64 years old the prevalence of risk factors for CVD such as obesity, diabetes mellitus, hypercholesterolemia and other cholesterol related risk factors grows $\operatorname{high}^{(7)}$.

In all countries of the Region, there is increasing awareness about CVD as a main cause of morbidity and mortality. A survey preformed in the year 2000 in Saudi Arabia showed the increasing number of elderly in Saudi Arabia and hence the increased number of cardiovascular patients, which is a good reason to investigate and provide a way to help those people to avoid or delay the incidence of having $\mathrm{CVD}^{(\mathbf{8})}$.

The aim of the present study is to provide a helpful test for the early diagnosis of CVD through measurement of changes in plasma $\mathrm{Na}^{+}, \mathrm{K}^{+}$-ATPase activity to predict CVD long before their development in elderly people.

\section{SUBJECTS \& METHODS}

Patients and normal controls included in this study were selected from King Fahad hospital in Madina area in the Mid-Western region of Saudi Arabia. A total of 115 subjects volunteered, (42 males and 73 females of 50-85 years of age). They were divided into two main groups. The first group consisted of 20 healthy 
normal controls. The second group consisted of 95 cardiovascular patients that composed of; 28 patients with valvular heart diseases, (VHD), 22 patients with ischemic heart diseases, (IHD), 15 patient with arrhythmia, (ARRY), 14 patient with heart failure, (HF) and 16 patient with hypertension, (HTN).

After an overnight fast a $4 \mathrm{ml}$ venous blood sample was collected from each subject in lithium heparin, (LH) tubes, and kept at room temperature. Plasma was separated from RBCs. The plasma was used to measure the biochemical parameters using the closed system of DADE BEHRING Dimension (RXL2), [Dimension Clinical System from DADE BEHRING Inc. Newark, DE 19714, USA].

RBC's were washed in isotonic saline three times. Finally, deionized water was added to the sediment and stored at $-20^{\circ} \mathrm{C}$ over night. After thawing, the supernatant was separated by centrifugation at 8000 $\mathrm{rpm}$ for $30 \mathrm{~min}$ at $4^{\circ} \mathrm{C}$, and the ghost, (sediment), was used for estimation of $\mathrm{Na}^{+}, \mathrm{K}^{+}$-ATPase activity.

The study included measurements of the following:

- Determination of the $\mathrm{Na}^{+}, \mathrm{K}^{+}$ATPase activity was performed by measuring the quantity of $\mathrm{Pi}$ released in the reaction from $\operatorname{ATP}^{(9)}$.

- Determination of total $\operatorname{protein}^{(\mathbf{1 0})}$ and glucose $\mathrm{e}^{(11)}$.

- Determination of lipid profile including :total cholesterol ${ }^{(12)}$; triglycerides ${ }^{(13)}$;high density lipoproteins ${ }^{(14)}$ and low density lipoproteins (LDL), as calculated according to Tietz $^{(15)}$.
- Determination of sodium, potassium and chloride ${ }^{(16)}$.

- Determination of magnesium ${ }^{(\mathbf{1 7})}$; calcium $^{(18)}$ and phosphorous ${ }^{(19)}$.

- Determination of creatine kinase ${ }^{(20)}$; aspartate aminotransferase $(\mathrm{AST})^{(\mathbf{2 1})}$, alanine aminotransferase $(\mathrm{ALT})^{(22)}$, and lactate dehydrogenase $(\mathrm{LDH})^{(23)}$.

\section{Statistical analysis}

Student t-test was used to compare between group means. The $\mathrm{p}$-value was considered to be statistically significant if $\mathrm{p} \leq 0.05^{(24)}$.

\section{RESULTS}

Table (1) shows plasma $\mathrm{Na}^{+}, \mathrm{K}^{+}-$ ATPase activity in the studied groups. In the normal control group plasma $\mathrm{Na}^{+}, \mathrm{K}^{+}$-ATPase activity was found to be $0.72 \cdot 10^{-3} \pm 0.018 \cdot 10^{-3} \mu \mathrm{mol}$ $\mathrm{Pi} /$ min.mg. protein. The valvular heart disease group (VHD), has measured $1.80 \cdot 10^{-3} \pm 0.136 \cdot 10^{-3} \mu \mathrm{mol} \mathrm{Pi} / \mathrm{min}$. $\mathrm{mg}$. protein, which is significantly higher than the normal control group, $(\mathrm{p}<0.001)$. In the heart failure group (HF), the activity was $1.3 \cdot 10^{-3} \pm$ $0.117 \cdot 10^{-3} \mu \mathrm{mol} \mathrm{Pi} / \mathrm{min} . \mathrm{mg}$ protein, which is also significantly higher than the control group, $(\mathrm{p}<0.05)$. The highest activity was found in the ischemic heart disease group (IHD), of value $2.31 \cdot 10^{-3} \pm 0.252 \cdot 10^{-3}$ $\mu \mathrm{mol} \mathrm{Pi} / \mathrm{min}$. mg. protein, which is significantly higher than control group, $(\mathrm{p}<0.001)$.

In arrhythmia group (Arry), the activity was $0.76 \cdot 10^{-3} \pm 0.07 \cdot 10^{-3}$ $\mu \mathrm{mol} \mathrm{Pi} / \mathrm{min}$. mg. protein, while in the hypertension group (HTN), it was $0.73 \cdot 10^{-3} \pm 0.14 \cdot 10^{-3} \mu \mathrm{mol} \mathrm{Pi} / \mathrm{min}$. mg. protein. Both are non- 
significantly different from the normal

controls.

Table (1): Plasma $\mathrm{Na}^{+}, \mathrm{K}^{+}$-ATPase activity, (mean \pm S.D), in the different patients groups as compared to the control group.

\begin{tabular}{|c|c|c|c|}
\hline GROUP & $\mathbf{n}$ & $\begin{array}{c}\mathbf{N a}^{+}, \mathbf{K}^{+} \text {-ATPase } \\
\boldsymbol{\mu m o l ~ P i / m i n . ~ m g . ~ p r o t e i n ~}\end{array}$ & $\mathbf{p}$-Value \\
\hline CONTROL & 20 & $0.72 \cdot 10^{-3} \pm 0.018 \cdot 10^{-3}$ & --- \\
\hline VHD & 28 & $1.80 \cdot 10^{-3} \pm 0.136 \cdot 10^{-3}$ & $\mathrm{p}<0.001$ \\
\hline IHD & 22 & $2.31 \cdot 10^{-3} \pm 0.252 \cdot 10^{-3}$ & $\mathrm{p}<0.001$ \\
\hline HF & 14 & $1.3 \cdot 10^{-3} \pm 0.117 \cdot 10^{-3}$ & $\mathrm{p}<0.050$ \\
\hline ARRY & 15 & $0.76 \cdot 10^{-3} \pm 0.07 \cdot 10^{-3}$ & N.S. \\
\hline HTN & 16 & $0.73 \cdot 10^{-3} \pm 0.14 \cdot 10^{-3}$ & N.S. \\
\hline
\end{tabular}

\section{N.S. = non-significant}

Table (2) shows plasma $\mathrm{Na}, \mathrm{K}$, $\mathrm{Mg}, \mathrm{Ca}, \mathrm{Cl}$, and $\mathrm{P}$ in the different patients groups as compared to the normal control group. Non-significant differencies have been noticed for plasma sodium and Calcium.

However, plasma potassium of the ischemic heart disease group (IHD), with a value of $3.859 \pm 0.097$ $\mathrm{mmol} / \mathrm{L}$ was significantly lower than the control group, $(\mathrm{p}<0.05)$. As for plasma magnesium only the heart failure group (HF), with value of $0.583 \pm 0.159 \mathrm{mmol} / \mathrm{L}$, was found highly significant lower than the control group, $(\mathrm{p}<0.001)$.

Plasma chloride showed two significantly lower values than the control group; of $65.733 \pm 20.82$ $\mathrm{mmol} / \mathrm{L},(\mathrm{p}<0.05)$ in the heart failure group(HF), and of $100.645 \pm 0.76$ $\mathrm{mmol} / \mathrm{L}, \quad(\mathrm{p}<0.05), \quad$ in the hypertension group (HTN), respectively, while for plasma phosphorus the only significantly different value was the lower value of the valvular heart disease group (VHD), of $1.004 \pm 0.034 \mathrm{mmol} / \mathrm{L},(\mathrm{p}<$ $0.05)$.

Table (2): Plasma Na, K, Mg, Ca, Cl and P, (mean \pm S.D), in the different patients groups as compared to the control group.

\begin{tabular}{|c|c|c|c|c|c|c|}
\hline GROUP & $\mathbf{N a ~ m m o l} / \mathbf{L}$ & $\mathbf{K ~ m m o l} / \mathbf{L}$ & $\mathbf{M g ~ m m o l} / \mathbf{L}$ & $\mathbf{C a ~} \mathbf{~ m o l} / \mathbf{L}$ & $\mathbf{C l ~} \mathbf{~ m m o l} / \mathbf{L}$ & $\mathbf{P} \mathbf{~ m m o l} / \mathbf{L}$ \\
\hline CONTROL & $138.05 \pm 0.71$ & $4.171 \pm 0.011$ & $0.793 \pm 0.067$ & $2.318 \pm 0.039$ & $88.353 \pm 8.09$ & $1.147 \pm 0.051$ \\
\hline VHD & $136.13 \pm 0.87$ & $4.056 \pm 0.095$ & $0.653 \pm 0.064$ & $2.306 \pm 0.038$ & $78.624 \pm 8.06$ & $1.004 * \pm 0.034$ \\
\hline IHD & $135.59 \pm 0.89$ & $3.859^{*} \pm 0.097$ & $0.716 \pm 0.076$ & $2.294 \pm 0.034$ & $83.791 \pm 9.52$ & $1.098 \pm 0.068$ \\
\hline HF & $135.59 \pm 0.86$ & $3.899 \pm 0.19$ & $0.583^{* *} \pm 0.159$ & $2.230 \pm 0.062$ & $65.733^{*} \pm 0.82$ & $1.103 \pm 0.086$ \\
\hline ARRY & $138.08 \pm 1.06$ & $4.142 \pm 0.13$ & $0.678 \pm 0.102$ & $2.249 \pm 0.059$ & $81.120 \pm 13.56$ & $1.054 \pm 0.045$ \\
\hline HTN & $137.75 \pm 0.96$ & $4.023 \pm 0.11$ & $0.819 \pm 0.023$ & $2.259 \pm 0.031$ & $100.645^{*} \pm 0.76$ & $1.036 \pm 0.050$ \\
\hline
\end{tabular}


Table (3) shows plasma glucose, urea and creatinine in the different patients groups as compared to the control group. The normal control group showed a plasma glucose value of $5.55 \pm 0.195 \mathrm{mmol} / \mathrm{L}$.

Only two groups, namely; the valvular heart disease group (VHD), and the heart failure group, (HF), scored significantly higher, $(\mathrm{p}<0.05)$, with values of $7.55 \pm 1.03 \mathrm{mmol} / \mathrm{L}$ and $9.13 \pm 1.25 \mathrm{mmol} / \mathrm{L}$ respectively.

With respect to plasma urea the same two groups differed significantly, $(p<0.05)$, from the normal control group which had a value of $6.857 \pm 1.08 \mathrm{mmol} / \mathrm{L}$. The valvular heart disease group(VHD), showed the lowest value of $5.186 \pm$ $1.933 \mathrm{mmol} / \mathrm{L}$ and the heart failure group (HF), showed the highest value of $10.20 \pm 2.25 \mathrm{mmol} / \mathrm{L}$.

Only the heart failure group (HF), with plasma creatinine value $162.60 \pm$ $29.18 \mathrm{mmol} / \mathrm{Lwas}$ found to be significantly higher, $(\mathrm{p}<0.05)$, than the norml control value of $105.38 \pm 5.18$ $\mathrm{mmol} / \mathrm{L}$.

Table (3): Plasma Glucose, Urea and Creatinine, (mean \pm S.D), in the different patients groups as compared to the control group.

\begin{tabular}{|c|c|c|c|}
\hline GROUP & $\begin{array}{c}\text { Glucose } \\
\mathbf{m m o l} / \mathbf{L}\end{array}$ & $\begin{array}{c}\text { Urea } \\
\mathbf{m m o l} / \mathbf{L}\end{array}$ & $\begin{array}{c}\text { Creatinine } \\
\mathbf{m m o l} / \mathbf{L}\end{array}$ \\
\hline CONTROL & $5.55 \pm 0.195$ & $6.857 \pm 1.08$ & $105.38 \pm 5.18$ \\
\hline VHD & $7.55^{*} \pm 1.03$ & $5.186^{*} \pm 1.933$ & $80.96 \pm 27.401$ \\
\hline IHD & $6.90 \pm 0.73$ & $7.23 \pm 0.87$ & $111.87 \pm 15.73$ \\
\hline HF & $9.13 * \pm 1.25$ & $10.20 * \pm 2.25$ & $162.60 * \pm 29.18$ \\
\hline ARRY & $6.23 \pm 1.10$ & $7.93 \pm 1.43$ & $100.55 \pm 23.90$ \\
\hline HTN & $6.18 \pm 0.45$ & $6.73 \pm 1.24$ & $90.75 \pm 13.14$ \\
$* * \mathrm{p}<0.05$ & & & \\
$* *=\mathrm{p}<0.001$ & & &
\end{tabular}

Table (4) shows the plasma lipid profile of the different patients groups as compared to the normal control group. Plasma triglycerides of $1.67 \pm$ $0.14 \mathrm{mmol} / \mathrm{Lwas}$ recorded for the normal control group. Only the ischemic heart disease group (IHD), with the lower value of $1.11 \pm 0.11$ $\mathrm{mmol} / \mathrm{L}$, was found to be significantly different, $(\mathrm{p}<0.05)$.

Plasma cholesterol was found to be $4.99 \pm 0.315 \mathrm{mmol} / \mathrm{L}$ in the normal control group. Only the heart failure group (HF), with a value of $5.62 \pm$ $0.44 \mathrm{mmol} / \mathrm{L}$, was found to be significantly higher than the control group, $(\mathrm{p}<0.05)$.

Plama HDL value of $0.92 \pm 0.14$ $\mathrm{mmol} / \mathrm{L}$ was found in the normal control group. Two of the patient group had significantly higher values namely; the hypertension group $(\mathrm{HTN})$, with $1.37 \pm 0.23 \mathrm{mmol} / \mathrm{L},(\mathrm{p}<$ $0.05)$, and the heart failure group $(\mathrm{HF})$, with $1.57 \pm 0.57 \mathrm{mmol} / \mathrm{L},(\mathrm{p}<$ 0.01 ). As for plasma LDL a value of $3.163 \pm 1.52 \mathrm{mmol} / \mathrm{L}$ was recorded for the normal control group, with a significantly higher value of $3.367 \pm$ $1.023 \mathrm{mmol} / \mathrm{L}$ for the arrhythmia group (Arry), $(\mathrm{p}<0.050)$. 
Table (4): Plasma Lipid Profile, (mean \pm S.D), in the different patients groups as compared to the control group.

\begin{tabular}{|c|c|c|c|c|}
\hline GROUP & $\begin{array}{c}\text { Triglycerides } \\
\text { mmol/L }\end{array}$ & $\begin{array}{c}\text { Cholesterol } \\
\mathrm{mmol} / \mathrm{L}\end{array}$ & $\begin{array}{c}\mathrm{HDL} \\
\mathrm{mmol} / \mathrm{L}\end{array}$ & $\begin{array}{c}\mathrm{LDL} \\
\mathrm{mmol} / \mathrm{L}\end{array}$ \\
\hline CONTROL & $1.67 \pm 0.14$ & $4.99 \pm 0.315$ & $0.92 \pm 0.14$ & $3.163 \pm 1.52$ \\
\hline VHD & $1.45 \pm 0.18$ & $4.55 \pm 0.18$ & $1.07 \pm 0.10$ & $2.853 \pm 0.796$ \\
\hline IHD & $1.11 *_{ \pm 0.11}$ & $4.29 \pm 0.31$ & $1.24 \pm 0.36$ & $2.731 \pm 1.142$ \\
\hline HF & $1.34 \pm 0.18$ & $5.62 * \pm 0.44$ & $1.57 * *_{ \pm} 0.57$ & $3.140 \pm 1.412$ \\
\hline ARRY & $1.38 \pm 0.12$ & $4.60 \pm 0.35$ & $0.91 \pm 0.11$ & $3.367 * \pm 1.023$ \\
\hline HTN & $1.51 \pm 0.19$ & $4.92 \pm 0.19$ & $1.37 * \pm 0.23$ & $2.750 \pm 1.007$ \\
\hline
\end{tabular}

Table (5) shows the plasma CK, LDH, AST and ALT of the different patients groups as compared to the normal control group. The normal control group had a plasma CK value of $82.62 \pm 10.50 \mathrm{U} / \mathrm{L}$. Only the heart failure group (HF), with the higher value of $433.714 \pm 175.49 \mathrm{U} / \mathrm{L}$ was found to be significantly different from control group, $(\mathrm{p}<0.001)$. The same pattern applies for plasma LDH with a normal control value of $184.195 \pm 7.44 \mathrm{U} / \mathrm{L}$ and a heart failure group (HF), value of $263.714 \pm 42.94$ $\mathrm{U} / \mathrm{L},(\mathrm{p}<0.001)$.
Plasma AST in normal control group recorded $24.52 \pm 1.34 \mathrm{U} / \mathrm{L}$. The arrhythmia group (Arry), had a value of $40.82 \pm 7.87 \mathrm{U} / \mathrm{L}$, which is significantly higher than the control group, $(\mathrm{p}<0.001)$. The heart failure group (HF), matched with a value of $49.86 \pm 14.48 \mathrm{U} / \mathrm{L},(\mathrm{p}<0.001)$. The same pattern applies to plasma ALT of $37.69 \pm 3.42 \mathrm{U} / \mathrm{L}$ in the normal control group and a significantly higher values of $46.657 \pm 7.96 \mathrm{U} / \mathrm{L}$, $(\mathrm{p}<0.05)$ and $53.591 \pm 11.14 \mathrm{U} / \mathrm{L}$, $(\mathrm{p}<0.005)$, for the heart failure group (HF), and the arrhythmia group (Arry), respectively.

Table (5): Plasma CK, LDH, AST and ALT, (mean \pm S.D), in the different patients groups as compared to the control group.

\begin{tabular}{|c|c|c|c|c|}
\hline GROUP & CK U/L & LDH U/L & AST U/L & ALT U/L \\
\hline CONTROL & $82.62 \pm 10.50$ & $184.195 \pm 7.44$ & $24.52 \pm 1.34$ & $37.69 \pm 3.42$ \\
\hline VHD & $105.68 \pm 37.69$ & $227.35 \pm 14.57$ & $29.82 \pm 2.84$ & $38.257 \pm 2.73$ \\
\hline IHD & $56.818 \pm 6.61$ & $190.05 \pm 9.36$ & $24.00 \pm 1.82$ & $35.217 \pm 4.38$ \\
\hline \multirow{2}{*}{ HF } & $433.714^{* * *}$ & $263.714^{* * *}$ & $49.86^{* * *}$ & $46.657 *$ \\
& \pm 175.49 & \pm 42.94 & \pm 14.48 & \pm 7.96 \\
\hline \multirow{2}{*}{ ARRY } & $57.27 \pm 12.29$ & $204.046 \pm 18.73$ & $40.82^{* * *}$ & $53.591 * *$ \\
& & & \pm 7.87 & \pm 11.14 \\
\hline HTN & $44.688 \pm 6.18$ & $172.844 \pm 10.31$ & $22.94 \pm 2.12$ & $33.675 \pm 3.79$ \\
\hline
\end{tabular}




\section{DISCUSSION}

Cardiovascular disease (CVD), is common in the elderly and affect $50 \%$ of those over the age of 65 years. It is the leading cause of death for the age range 65-74 years, (Lye et al., 2000). Hypercholesterolemia has been recognized as direct and independent risk factors for CVD and recognized as the most important modifiable risk factor where early diagnosis and therapy can reduce incidence of CVD events.

Saudi Arabia has witnessed significant urbanization over the last 40 years with significant improvement in social and economic status resulting in huge changes in lifestyle, accommodating more of the "Western" style with respect to diet and physical activity. Saudi Arabia's ecology results in wide variations in the life style and food consumption patterns which might be a major underlying cause of the variation and high prevalence of coronary artery disease risk factors ${ }^{(26)}$. Another survey showed that features of insulin resistance syndrome (IRS), are widely prevalent among the Saudi population over the age of 40 years. IRS is a probable significant contributor to the pathologic process of CVD among the Saudi population, especially in view of the low prevalence of hypercholesterolemia ${ }^{(27)}$.

Several studies have shown that $\mathrm{Na}^{+}, \mathrm{K}^{+}$-ATPase activity decrease in heart tissues in CVD patients $\left.{ }^{(28} \& 29\right)$. In the present study $\mathrm{Na}^{+}, \mathrm{K}^{+}$-ATPase activity was found to be significantly higher in 3 out of 5 CVD patients groups. This contradicts the results of
Dai et $\mathrm{al}^{(30)}$, who found that $\mathrm{Na}^{+}, \mathrm{K}^{+}$ATPase activity was significantly lower by $16 \%$, in CVD. The increase in $\mathrm{Na}^{+}, \mathrm{K}^{+}$-ATPase activity of most CVD patients groups could be attributed to the pharmacological and surgical treatment, since almost 95\% of the patients were already treated surgically or pharmaceutically, which agrees well with Vrbjar et al., and Fuller et al. $\left.{ }^{(31} \&{ }^{32}\right)$. In arrhythmia (ARRY), and hypertensive (HTN), patients $\mathrm{Na}^{+}, \mathrm{K}^{+}$-ATPase activity showed almost the same activity of age matched healthy normal controls, which agrees well with results from Zavecz \& Dutta, and Dai et al. ${ }^{(33 \& 30)}$.

All patient groups varied in showing significant decrease in various plasma electrolytes. This agrees with the fact that plasma electrolytes remain constant or slightly decreases with advancing $\operatorname{age}^{(34)}$.

Plasma glucose was found to be significantly higher in heart the failure (HF), group than the normal control group. This agrees well with the findings of Iribarren et al. ${ }^{(35)}$, who stated that poor glycemic control in elderly population may be associated with an increased risk of heart failure. As for the significant increase in plasma glucose level in the valvular heart disease (VHD), it goes well with the study of Podlesny ${ }^{(36)}$ who found that diabetes has an influence on the morphology of the heart seen as hypertrophy of the left ventricle.

Plasma urea and creatinine were found highest in the heart failure group. This goes well with the study of Nilsson et al. ${ }^{(37)}$, who showed that heart failure is associated with 
impaired creatinine clearance and increased urea and creatinine.

The lowest triglyceride found in ischemic heart disease group could be attributed to treatment, since its increase is one of the factors that induce ischemic heart diseases ${ }^{(38)}$.

The highly significant increase in plasma cholesterol found in the heart failure group agrees with Nilsson et al. ${ }^{(37)}$ who showed that cholesterol increases in congestive heart failure.

Low HDL is an important risk factor for CVD death in the elderly; high HDL has significant protective effect against coronary artery disease $^{(39)}$. The highly significant increase in plasma HDL in the heart failure and the hypertension groups points to its control by treatment. However, plasma LDL showed a nonsignificant decreased except in the arrhythmia group which showed a significantly higher value pointing again to the variable effects of treatment.

Cardiac enzyme marker CK, LDH, AST and ALT showed significant higher activities in heart failure patients. ALT showed an unexplaned sole significant increase in arrhythmia patients.

In view of the results of all the classical laboratory diagnostic tests it could be conclude that plasma $\mathrm{Na}^{+}$, $\mathrm{K}^{+}$-ATPase activity has been proved as a helpful additional laboratory diagnostic test for the early diagnosis and prognosis of cardiovascular diseases while advancing in age.

\section{REFERENCES}

1. Amano, M., Imataka, K., Suzuki, K., Nakaoka, H. and
Fujii, J. (1989). Age-related reduction in the number of rabbit erythrocytes Na- K+ ATPase. Tohoku J Exp Med. 159(2):1317.

2. Kagamimori, S., Nakagawa, H., Tsujikawa, K., Naruse, Y., Okumura, Y., Kawano, S., Fujita, T. and Watanabe, $M$. (1986). $\mathrm{Na}^{+}, \mathrm{K}^{+}$-ATPase activity of erythrocyte membrane correlated with urinary $\mathrm{Na}^{+} / \mathrm{K}^{+}$ ratio in normotensive adolescents with a family history of hypertension. $J$ Clin Exp Hypertens. 8 (3): 309-21.

3. Kroening, B. H. and Weintraub, M. (1980). Ageassociated differences in guinea pig myocardial $\mathrm{Na}^{+}, \mathrm{K}^{+}$-ATPase activity and ouabain inhibition and in $\mathrm{Mg}^{+2}$-ATPase activity. $J$ Pharmacology. 21(3): 193-7.

4. Kjeldsen, K., and GrØn , P. (1990). Age-dependent change in myocardial cardiac glycoside receptor $\quad \mathrm{Na}^{+}, \quad \mathrm{K}^{+}$-pump concentration in children. $J$ Cardiovasc Pharmacol. (15): 2 332-7.

5. Norgaard, A., Bjerregaard, P., Baandrup, U., Kjeldsen, K., Reske, N. E. and Thomsen, P. E. (1990). The concentration of the $\mathrm{Na}^{+}, \mathrm{K}^{+}$-pump in skeletal and heart muscle in congestive heart failure. Int Cardiol. 26 (2): 185-90.

6. Sudhakar, K., Sujatha, M., Devi, C. V. and Reddy, P. P. (1998). Sodium and $\mathrm{Na}^{+}, \mathrm{K}^{+}$ATPase activity in untreated hypertensives and their first degree relatives. Indian $J$ Biochem Biophys. 35 (6): 382-4. 
7. Al-Nuaim R. A. (1997). High prevalence of metabolic risk factors for cardiovascular diseases among Saudi population, aged 30-64 years. Int J Cardiol. 62(3): 227-35.

8. Saudi online (2000). People and Health Services, Saudi Arabia the country in brief. http://www.saudiaonline.com/sau di arabia.htm\#people.

9. Fiske, C. and Subbarow, Y. (1925). The colorimetric determination of phosphorus. $J$. Biol. Chem. (66): 375-400.

10. Gornall, A. G., Bardawill, G. J. and David, M. M. (1949). Determination of serum protein by means of the biuret reaction. $J$ Biol Chem. (177): 751-60.

11. Kunst, A., Draeger, B., Ziegenhorn, J. (1983). UVmethods with hexokinase and glucose-6-phosphate

dehydrogenase. Methods of enzymatic analysis. Vol VI. Bergmeyer HU, Ed, Verlag Chermie, Deerfield.

12. Flegg, H. M. (1973). An investigation of the determination of serum cholesterol by an enzymatic method. Ann Clin. Biochem. (10): 79-84.

13. Rautela, G. S., Hall R. G, Jr., Bekiesz, C. L. and Wermus, G. R. (1974). A Kinetic method for rapid and automatic measurement of triglycerides in biological fluids. Clin Chem. (20): 857-861.

14. Warnick, G. R. and Wood, P. D. (1995). National cholesterol education program recommendations for measurement of high-density lipoprotein cholesterol: Executive summary. Clin Chem. (41): 1427-1433.

15. Tietz, N. W. (1987). Fundamentals of clinical chemistry. $3^{\text {ed }}$ edition. W.B. Saunders Co., Philadelphia, USA.

16. Stenberg, J. C., Uplike, S. J., Lehane, D. P. (1976). Selective electrode sensors, in microtechniques for the clinical laboratory. Concepts and Applications, M. Wener, ED, New York: John Wiley and Sons.

17. Connerty, H. V., Lau, S. H. C., and Briggs, A. R. (1971). Presented at the $23^{\text {rd }}$ national meeting of the American Association of Clinical Chemistry. Clin Chem, 17:661.

18. Connerty, H. V. and Briggs, A. R. (1966). Determination of serum calcium by means of ocresolphthalein complexone. Am J Path. 45: 290-296.

19. Goodwin, J. F. (1970). Quantification of serum inorganic phosphorus, phosphatase, and urinary phosphate without preliminary treatment. Clin Chem. 16: 776-83.

20. Thompson, W. H. S. (1969). An investigation of physical factors influencing the behavior in vitro of serum creatine phosphokinase and other enzymes. Clin Chem. (23): 105-120.

21. Saris, N. E. (1978). Revised IFCC method for aspartate aminotransferase. Clin chem. (24): 720-721.

22. Bergmeyer, H. U., Scheibe, P. and Wahlefeld, A. W. (1978). Optimization of methods for aspartate aminotransferase and 
alanine aminotransferase. Clin Chem. 24 (1): 58-73.

23. Gay, R. J., McComb, R. B. and Bowers, G. N., Jr. (1968). Optimum reaction conditions for human lactate dehydrogenase isoenzymes as they affect total lactate dehydrogenase activity. Clin Chem. (14): 740-46.

24. Marija, J. N. (1985). SPSS/PC ${ }^{+}$ for the IBM PC/XT/AT.SPSS INC. Chicago, USA.

25. Lye, M., King, D., Merry, M., Jack, C., O'Keeffe, S., Barrett, J., Gosney, M., Smith, S., Carroll, N., Rhodes, L., Finlayson, C., Heffer, C., Benbow, S., Playfer, J., Shea, T., Wills, D., Watkins, C., Hammond, M., Entwistle, J. and Phillips, G. (2000). Liverpool Handbook of Geriatric Medicine. University of Liverpool, UK.

26. Osman, A. K. and Al-Nozha, $M$. M. (2000). Risk factors of coronary artery disease in different regions of Saudi Arabia. East Medterr Health J. 6 (2-3): 465-74.

27. Al-Nuaim R. A. (1997). High prevalence of metabolic risk factors for cardiovascular diseases among Saudi population, aged 30-64 years. Int J Cardiol. 62(3): 227-35.

28. Norgaard, A., Bjerregaard, P., Baandrup, U., Kjeldsen, K., Reske, N. E. and Thomsen, P. E. (1990). The concentration of the $\mathrm{Na}^{+}, \mathrm{K}^{+}$-pump in skeletal and heart muscle in congestive heart failure. Int Cardiol. 26 (2): $185-90$
29. Sudhakar, K., Sujatha, M., Devi, C. V. and Reddy, P. P. (1998). Sodium and $\mathrm{Na}^{+}, \mathrm{K}^{+}$ATPase activity in untreated hypertensives and their first degree relatives. Indian $J$ Biochem Biophys. 35 (6): 382-4.

30. Dai, K. S., Liang, C. S., Chiu, Y. T., Yang, P. C. and Cheng, I. C. (1995). Alterd adenosine triphosphatase activities in pigs with naturally occurring hypertrophic cardiomyopathy. Vet Res Commun. 19 (2):115-25.

31. Vrbjar, N., Slezak, J., Ziegelhoffer, A. and Tribulova, N. (1991). Features of the $\mathrm{Na}^{+}$, $\mathrm{K}^{+}$-ATPase cardiac sarcolemma with particular reference to myocardial ischemia. Eur Heart J. (12): 149-52.

32. Fuller W., Eaton P., Bell J.R.and Shattock M.J., ( 2003). Ischemia-induced

phosphorylation of phospholemman directly activates rat cardiac $\mathrm{Na} / \mathrm{K}$-ATPase., FASEB J., 18 (1) 197-9.

33. Zavecz, I. H. and Dutta, S. (1977). The relationship between $\mathrm{Na}^{+}, \mathrm{K}^{+}$-ATPase inhibition and cardiac glycoside-induced arrhythmia in dogs. Naunyn Schmiedebergs Arch Pharmacol. 297 (1): 91-8.

34. Bishop, M. L., DubenEngeelkirk, J. and Fody, E. P. (1996). Clinical Chemistry, Principle, Procedures, Correlations. $\quad 3^{\text {ed }}$ edition. Lippincott-Raven Publishers, Philadelphia, USA. 
35. Iribarren, C., Karter, A. J., Go, A. S., Ferrara, A., Liu, J. Y., Sidney, S. and Selby, J. V. (2001). Glycemic control and heart failure among adult patients with diabetes. Circulation. 103(22):2668-73

36. Podlesny, M. (2003). Diabetic cardiomyopathy. Pol Merkuriusz Lek. 15(89): 476-9.36.

37. Nilsson, S. E., Takkinen, S., Tryding, N., Evrin, P. E., Berg, S., McClearn, G. and Johansson, B. (2003). Association of biochemical values with morbidity in the elderly: a population-based Swedish study of persons aged 82 or more years. Scand J Clin Lab Invest. 63(7-8): 457-66.

38. Hokanson, J. E. (2002). Hypertriglyceridemia and risk of coronary heart disease. Curr Cardiol Rep. 4 (6): 488-93.

39. Li, P. W., H. O., C. S. and Swaminathan, R. (1994). The effect of high salt intake on $\mathrm{Na}^{+}$, $\mathrm{K}^{+}$-ATPase activity of tissues in the rat. Clin Exp Hypertens. 16 (3): 327-40. 


\section{ملخص باللغة العربية}

تعتبر أمراض القلب الوعائية السبب الأساسى للموت المبكر بما نسبته حوالى هץ\% من الوفيات على مستوى العالم.

وأمراض القلب الوعائية هى النتيجة النهائية لتكامل عدد من عوامل الخطورة كالتقدم فى السن والسمنة وأرتفاع نسبة الكوليستيرول فى الدموأرتفاع ضغط الدم ومرض السكرى والتناخين ونمط الحباة.

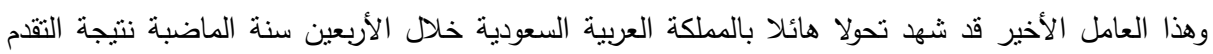

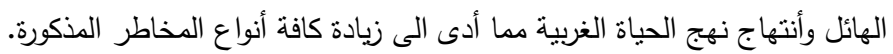
والهدف من هذه الدراسة هو نقديم أختبار يمكنه أن يساعد على التشخيص المبكر لأمراض القلب الوعائية

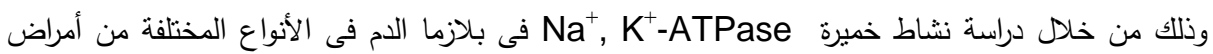
القلب الوعائية مثل حلات فثل القلب وأحتقان القلب وخلل صمامات القلب وغيرها ومحاولة ربط النتائج بالقياسات المعملبة الأخرى مثل قياسات خمائر وظائف القلب وسكر الدم ووظائف الكلى والكبد ذات الصلة.

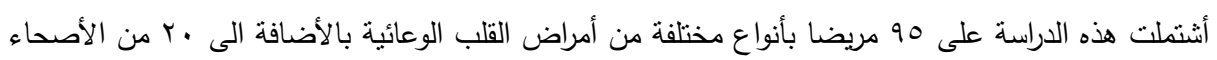

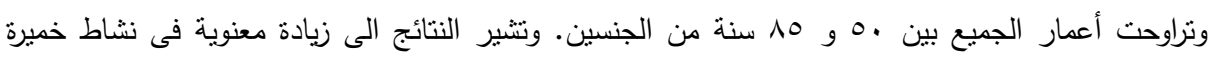

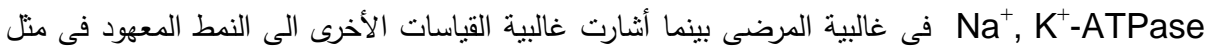
هذه الحالات. ويمكن القول بوجوب أضافة أختبار خميرة Na+, K+ATPase فى بلازما الدم كأختبار للكثف المبكر عن أمراض القلب الوعائية. 